\title{
Trust And Commitment As Mediators Of The Relationship Between Quality Advice And Customer Loyalty
}

Estelle van Tonder, North-West University, South Africa

\begin{abstract}
Insurance agents globally struggle with clients who do not understand the importance of disciplined savings and of meeting with them at least once a year to make necessary adjustments to their financial plans. The purpose of the study was to provide assistance to these agents and explore trust and commitment as mediators of the relationship between quality advice and customer loyalty. The context of the study was clients of independent insurance agents $(N=242)$, and self-administered surveys were used to test the research hypotheses formulated. It appears imperative for insurance agents providing clients with quality advice to focus strongly on building trust and commitment. These mediating variables contribute to a $27 \%$ change in the adjusted $R^{2}$ value, and resulted in a much higher $R^{2}$ value of 0.77 in the final model. The findings of the study could also assist larger organisations focusing on consultative selling practices and help them create solid client relationships with the potential to deliver great profit.
\end{abstract}

Keywords: Commitment; Customer Loyalty; Financial Services; Quality Advice; Trust

\section{INTRODUCTION}

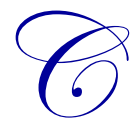

ustomer loyalty has been described as fundamental to marketing scholarship (Toufaily, Ricard, \& Perrien, 2013) and is generally perceived as an organisation's most enduring asset (Pan, Sheng, \& Xie, 2012, p. 150). The benefits of loyal customers are well documented. Loyal customers tend to make a greater volume of purchases on a more frequent basis, are less prone to defect to a competitive provider, and through word-of-mouth communication will recruit more customers for the organisation (Haywood, 1988; Oliver, 1999; Petrick, 2004; Shoemaker \& Lewis, 1999; Yoo \& Bai, 2013, p. 167). Loyal customers further offer great networking opportunities and provide the pathway for organisations to connect with other potential customers (Yoo \& Bai, 2013, p. 167). Customer loyalty is also positively associated with profitability (Anderson, Fornell, \& Lehmann, 1994; Leverin \& Liljander, 2006, p. 235; Reichheld, 1996) and it has been noted that a small increase in customer loyalty could result in a substantial increase in profit for the organisation (Reichheld, 1993; Reichheld \& Sasser, 1990; Yoo \& Bai, 2013, p. 167).

Customer loyalty therefore has the potential to contribute significantly to the success of the organisation, and insight into its predictors is essential for ensuring that customers remain loyal to the organisation over the long term. Roberts-Lombard, Van Tonder, Pelser, and Prinsloo (2014, p. 25) are of the same opinion and state that particularly within the insurance industry knowledge of the factors impacting on customer loyalty is critical for ensuring that clients remain loyal to the insurance agent. This is because insurance agents perform the role of salespeople, are responsible for selling insurance products to prospective clients, and play an important role in a country's economy. The advice that insurance agents provide their clients can have a great influence on their financial and emotional well-being. Furthermore, financial products tend to be complex, and the assistance of an agent is required to ensure that clients plan appropriately for retirement (Hunt, Brimble, \& Freudenberg, 2011, p. 70). It is therefore essential for clients to remain loyal to their insurance agents and allow them to provide the necessary advice and support for their financial well-being over the long term.

Several antecedents of customer loyalty have already been published in academic literature, including factors such as perceived value, satisfaction, commitment and trust (Kandampully, Zhang, \& Bilgihan, 2015, p. 382; Pan, Sheng, 
\& Xie, 2012, p. 151; Yoo \& Bai, 2013, p. 168). While all these factors are important and could contribute to fostering customer loyalty, it has been found by Pan, Sheng, and Xie (2012, p. 157), in their meta-analytic study of the predictors of customer loyalty, that trust has a stronger effect than other antecedents on loyalty, and that their results uphold the findings of former studies (Garbarino \& Johnson, 1999; Ibanez, Hartmann, \& Calvo, 2006).

Within the context of the insurance industry, trust is also regarded as an important factor in building the relationship between a service provider and the customer (Hunt, Brimble, \& Freudenberg, 2011, p. 69). According to Yen, Liu, Tsai, and Lai (2012, p. 18), in the early stages of the relationship, trust between the customer and the service provider is particularly critical when warranties cannot be provided. The long-term success of the relationship too is dependent on whether the customer is able to trust the service provider. Insurance agents, however, cannot rely only on a trusting relationship with their clients; as Hunt, Brimble, and Freudenberg (2011, pp. 81-82) postulate within the context of the insurance industry, not only trust but also commitment has been found to be an important factor in the establishment of a quality relationship with the insurance agent. Essentially both client trust in the insurance agent as well as commitment to the financial planning relationship can have a direct impact on positive outcomes, such as remaining loyal towards the insurance agent (Yeske, 2010, p. 40).

Morgan and Hunt (1994) additionally discovered that communication can be regarded as a predictor of trust and commitment. Christiansen and DeVaney (1998) repeated the same study within the insurance agent context and found that of all the variables investigated, communication had the greatest impact on trust and commitment. Sharma and Patterson (1999) in their study within the financial planning environment found that communication with regards to the technical quality of advice provided had a positive impact on the client's trust as well as relationship commitment towards the insurance agent.

Consequently, within the context of the insurance industry, quality advice can be viewed as essential for the development of trust and commitment with customers and can be defined as the skill of the insurance agent to convey valuable and timely advice (Shafique, Ahmad, Abbass, \& Manzoor, 2015, p. 110; Sharma \& Patterson, 1999). From the selection of studies highlighted above it can further be observed that trust and commitment appear to be important antecedents of customer loyalty towards insurance agents as well, and because of their link to both quality advice and customer loyalty, additionally have the potential to serve as mediating variables in the relationship between quality advice and customer loyalty.

To date a vast number of studies have been conducted on the mediating role of trust, commitment or a combination of the two factors. These studies, however, have mainly focused on independent variables such as corporate reputation (Chang, 2013), service customisation (Coelho \& Henseler, 2012), relational benefits (Dagger \& Brien, 2010), brand experience (Iglesias, Singh, \& Batista-Foguet, 2011), loyalty programs (Ou, Shih, Chen, \& Wang, 2011) and other factors such as termination costs, special treatment benefits, social benefits, confidence benefits and opportunistic behaviours (O'Mahony, Sophonsiri, \& Turner, 2013). The mediating role of trust and commitment in the relationship between quality advice and customer loyalty has not been explored before within the context of the insurance agent environment specifically. As such, it was the aim of this study to address the gap that exists within the marketing literature. Specifically, it was hypothesised that quality advice has a significant positive indirect effect on customer loyalty, as mediated by trust and commitment. Such a finding would have important practical implications for insurance agents, as it would mean that they need to concentrate on the provision of quality advice and at the same time ensure that their actions would lead to clients trusting them and remaining committed to the relationship. From a business psychology perspective, the findings of the study could also have meaning to larger organisations in the financial industry and other sectors of the economy. Should an indirect relationship between quality advice and customer loyalty be confirmed, it would be imperative for organisations to obtain more insight into the fundamental principles required for engaging consultative personnel and ensuring that they are in a position to provide quality advice. It would also be important to obtain a greater understanding of the psychology behind client trust and commitment and the type of work atmosphere required for ensuring that employees are able to perform their role effectively in establishing the necessary bond with the customer. Insight into these matters could assist consultative personnel in fostering solid client relationships that have the potential to deliver great profit over the long term. 
The following sections provide more insight into the research constructs as well as the hypotheses that were formulated for this study.

\section{Customer Loyalty and Relationship Marketing}

Customer loyalty has been defined in many different ways. While seminal contributions were delivered by Jacoby and Chestnut (1978) as well as Dick and Basu (1994), the first comprehensive description of the construct was published only a few years later by Oliver $(1999$, p. 34), who defined the concept as "a deeply held commitment to rebuy or repatronize a preferred product/service consistently in the future, thereby causing repetitive same-brand or same brand-set purchasing, despite situational influences and marketing efforts having the potential to cause switching behaviour" (Harris \& Goode, 2004, p. 141). More recently, Pan, Sheng, and Xie (2012, p. 151) have professed customer loyalty to be "the strength of a customer's dispositional attachment to a brand (or service provider) and his/her intent to rebuy the brand (or repatronize the service provider) consistently in the future". Kandampully, Zhang, and Bilgihan (2015, p. 402) are further of the opinion that given the transforming role of the customer, where greater emphasis is placed on customer participation, customer loyalty should encompass concepts such as the co-creation of value, emotional engagement of customers, customer communities, and participation through social media.

While no consensus has been reached on a formal definition for customer loyalty, it seems that most researchers are in agreement that the construct of customer loyalty consists of a behavioural as well as an attitudinal dimension (Bowen \& Chen, 2001; Chaudhuri \& Holbrook, 2001; Dick \& Basu, 1994; Jones \& Taylor, 2007; Pan, Sheng, \& Xie, 2012, p. 156). The behavioural dimension of customer loyalty relates to actions such as repeat purchase or word-of-mouth recommendations, while the attitudinal dimension is concerned with the customer's level of affection towards the organisation (Kandampully, Zhang, \& Bilgihan, 2015, p. 381; Yoo \& Bai, 2013, p. 167). Consequently, based on this classification, the view of Yoo and Bai $(2013$, p. 167) was adopted for the purpose of this study. More specifically, Yoo and Bai (2013, p. 167) define customer loyalty as "a customer's repeat visitation or repeat purchase behaviour while including the emotional commitment or expression of a favourable attitude toward the service provider".

Customer loyalty is further regarded as an outcome of successful relationship marketing practices (Ndubisi, 2007, p. 103). Relationship marketing was initially defined as an approach followed by organisations to form relationships with customers and to ensure that these relationships are developed and sustained on a continuous basis (Berry, 1983). According to Ndubisi (2007, p. 99), Grönroos (1994) later noted that the aim of relationship marketing is to "to establish, maintain, and enhance relationships with customers and other partners, at a profit, so that the objectives of the parties involved are met". Relationship marketing as such can be viewed as a business strategy aimed at establishing and sustaining long-term relationships with customers that are mutually rewarding and which are achieved through having conversations with customers, treating customers as individual persons and fulfilling promises (Ndubisi, 2003a, 2003b; Ndubisi, 2007, p. 99; Rapp \& Collins, 1990). O'Malley and Tynan (2000) further point out that relationship marketing practices have a greater chance of being successful when high involvement goods or services are purchased, when customers can engage in personal dialogues and are willing to form relationships with organisations. Crosby, Evans, and Cowles (1990, pp. 68-69), from a similar perspective, note that various studies have indicated that effective relationship selling is vital when a customised and complex service is offered (Berry, 1983; Levitt, 1983; Lovelock, 1983), buyers do not have the necessary qualifications (Ghingold \& Maier, 1986), and business is conducted in a dynamic and uncertain environment (Zeithaml, 1981). Customers in the financial services industry experience many of these problems and it is therefore essential for insurance agents to form strong relationships with their clients.

Ultimately, the quality of the relationship between the agent (salesperson) and the client will determine the probability of continued business in future (Crosby, Evans, \& Cowles, 1990, p. 68), as relationship quality is positively associated with customer loyalty (Lin \& Ding, 2005; Rauyruen \& Miller, 2007; Yen, Liu, Tsai, \& Lai, 2012, p. 17). This behaviour has also been confirmed in the life insurance industry, where it was discovered that the quality of the relationship between the customer and the insurance agent has a direct impact on the continuance of the business relationship (Crosby, Evans, \& Cowles, 1990). 
While a vast number of factors have been associated with relationship quality, trust and commitment are two of the factors that have been examined most (De Wulf, Odekerken-Schröder, \& Lacobucci, 2001; Odekerken-Schröder, De Wulf, \& Schumacher, 2003; Roberts, Varki, \& Brodie, 2003; Walter, Muller, Helfert, \& Ritter, 2003; Yen, Liu, Tsai, \& Lai, 2012, p. 19). Moreover, within the context of the insurance industry, both these variables have also been found to be important antecedents in the establishment of a quality relationship with the insurance agent (Hunt, Brimble, \& Freudenberg, 2011, pp. 81-82).

Consequently, the remaining part of the literature review provides more insight into trust and commitment and the mediating role that these factors play in the quality advice and customer loyalty relationship.

\section{Trust as a Mediator of the Quality Advice and Customer Loyalty Relationship}

The concept of trust was initially defined as the willingness of one individual to depend on another individual in whose ability to act reliably and with integrity one has faith (Moorman, Deshpande, \& Zaltman, 1993; Morgan \& Hunt, 1994). Later studies revealed that the concept of trust is in fact a multi-dimensional construct comprising a number of facets, for example honesty and fairness (Morgan \& Hunt, 1994), competence and benevolence (Singh \& Sirdeshmukh, 2000), cognitive assessments of an individual's competence and trustworthiness, affective dimensions involving feelings of care and concern, and behavioural components such as the inclination to act (Sekhon, Shergill, \& Pritchard, 2013, pp. 2-5).

While many definitions of trust have been provided, Nguen and Mutum (2012, p. 407) are of the opinion that "there is nevertheless a common and shared notion that trust is a feeling of security based on the belief that favourable and positive intentions towards welfare are on the agenda, as opposed to lying or taking advantage of the vulnerability of others". This belief is also upheld by Yen, Liu, Tsai, and Lai (2012, p. 19), who state that "trust in relational sales contexts can be defined as a confident belief that the salesperson can be relied on to behave in such a manner that the long-term interest of the customer will be served". Within the context of this study, trust can therefore be regarded as the client's perceptions of the insurance agent's honesty as well as the feeling that the insurance agent listens to the client and acts in the client's best interest.

Morgan and Hunt (1994), in their seminal work on trust, further indicated that communication can be viewed as an important antecedent of trust. This relationship was later also confirmed by other authors (Christiansen \& DeVaney, 1998; Sharma \& Patterson, 1999) who conducted studies in the insurance agent environment. A positive relationship has also been found between the quality of advice provided and trust towards the agent (Sharma \& Patterson, 1999). Consequently, given the findings of previous research, it was expected that within the context of this study the insurance agent's quality advice would also have an impact on whether clients would trust them. Considering the work of Sharma and Patterson (1999), quality advice for the purpose of this study could further be interpreted as the customer's perception of the quality of information or advice related to the insurance products and financial planning decisions provided by the insurance agent. Lastly, many empirical studies have confirmed that trust can affect the customer's feelings of loyalty towards the organisation (Chiu et al., 2009; Ganesan, 1994; Gefen, 2000; Lee, 2005; Liu et al., 2005; Morgan \& Hunt, 1994; Sumaedi, Bakti, Rakhmawati, Astrini, Widianti, \& Yarmen, 2014, p. 271; Wen, Lan, \& Cheng, 2005; Yoo \& Bai, 2013, p. 167). As such, it was also anticipated that trust could have an impact on customer loyalty within the context of this study and, if this expectation was correct, could further play a mediating role in the relationship between quality advice and customer loyalty.

Consequently, the first three research hypotheses formulated for the study stated the following:

H1: Quality advice has a significant positive relationship with trust towards the insurance agent.

H2: Trust has a significant positive relationship with customer loyalty towards the insurance agent.

H3: Quality advice has a significant positive indirect effect on customer loyalty, as mediated by trust. 


\section{Commitment as a Mediator of the Quality Advice and Customer Loyalty Relationship}

The concept of commitment has been defined in many different ways as well. Seminal contributions have been delivered by Moorman, Deshpande and Zaltman (1993) and by Morgan and Hunt (1994), which collectively define the construct as an aspiration and maximum effort to maintain a relationship that is believed to have merit. Allen and Meyer (1990) conducted a study of the types of commitment employees might have towards their organisations and discovered that commitment is in fact operationalised with three sub-dimensions, namely affective, normative and calculative commitment. Affective commitment relates to an individual's aspiration to continue the relationship, normative commitment refers to an individual's feeling of duty to remain in the relationship, and calculative or continuance commitment refers to an individual's willingness to continue the relationship due to the fact that the sacrifices associated with terminating the relationship would be too great (Jones, Fox, Taylor, \& Fabrigar, 2010, p. 17). Since the initial publication of their work many articles have also appeared in peer-reviewed literature that verified the relevance of the three sub-constructs to the marketing domain (Bansal, Irving, \& Taylor, 2004; Barksdale, Johnson, \& Suh, 1997; Beatty, Reynolds, Noble, \& Harrison, 2012; Cater \& Zabkar, 2009; Lariviere, Keiningham, Cooil, Aksoy, \& Malthouse, 2014, p. 76).

Jones, Fox, Taylor, and Fabrigar (2010, p. 17) further profess that, in essence, the concept of commitment indicates a consumer's dedication as well as motivation to remain in a relationship and, considering the three sub-dimensions of commitment, is based on the customer's belief that he/she "wants to remain in the relationship", "should remain in the relationship" or "have to remain in the relationship" (Jones, Fox, Taylor, \& Fabrigar, 2010, p. 17). Consequently, within the context of this study, commitment can be regarded as consumers' belief that the agent has their best interest at heart (causing them to want to remain in the relationship), that the agent makes annual adjustments to suit their financial needs (causing them to feel they should remain in the relationship) and that doing business with the practice has been worthwhile (causing them to think they have to remain in the relationship).

Additionally, similar to the concept of trust, quality advice has also been identified as an important antecedent of commitment (Sharma \& Patterson, 1999), as stated earlier in this article. Consequently, it was also expected in this study that quality advice by the insurance agent would impact on whether clients would be committed to their insurance agents. More specifically, should the insurance agent provide quality advice to the client in terms of insurance products and financial planning, clients could believe that their commitment to the relationship would be worthwhile and would make an effort to connect at both an emotional and a cognitive level. Lastly, given the previously established relationships between quality advice and commitment as well as between commitment and customer loyalty (Hunt, Brimble, \& Freudenberg, 2011, pp. 81-82; Yeske, 2010, p. 40), it was also possible that commitment could further play a mediating role in the relationship between quality advice and customer loyalty.

As such, the last three research hypotheses formulated for the study stated the following:

H4: Quality advice has a significant positive relationship with commitment towards the insurance agent.

H5: Commitment has a significant positive relationship with customer loyalty towards the insurance agent.

H6: Quality advice has a significant positive indirect effect on customer loyalty, as mediated by commitment.

\section{METHODOLOGY OF THE STUDY}

Following the operationalisation of the research constructs in the previous sections, Figure 1 provides a summary of all the hypotheses that were formulated for further testing in this study. 
Figure 1. Conceptual model

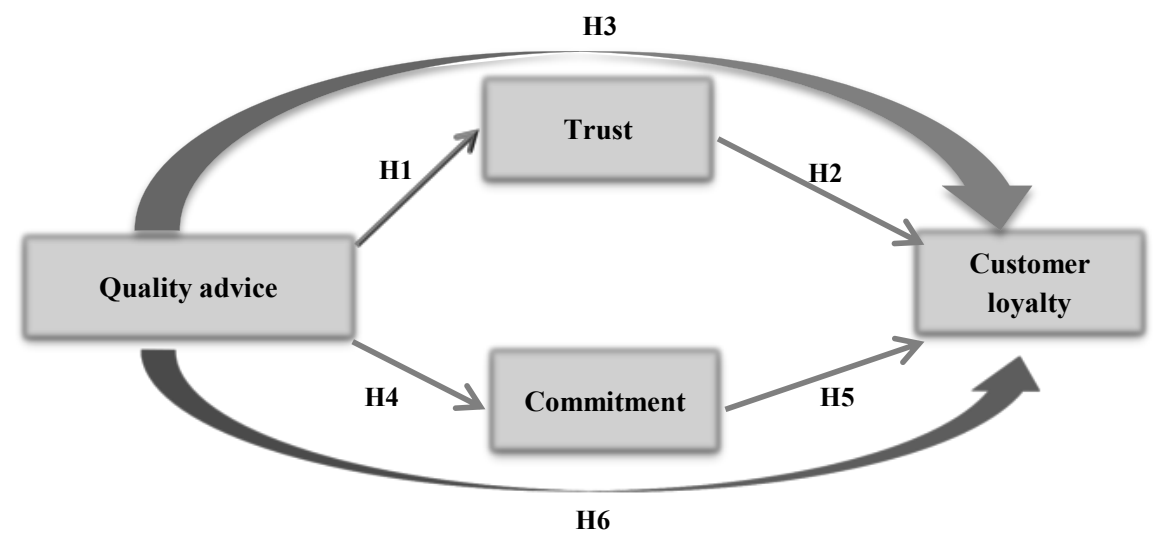

Source: Researcher's own construct

A cross-sectional study that was exploratory and quantitative in nature was designed to test the research hypotheses formulated. The context of the study was clients of independent insurance agents in South Africa. (Independent insurance agents normally operate a small business and sell the financial products of insurance companies to clients. They are not employed by the insurance company and only receive commission for their services delivered.) The target population included all respondents in South Africa that purchased a financial services product from their insurance agents in the last ten years. A ten-year period was selected as it was argued that financial services products are purchased on an infrequent basis. A convenience sampling method was applied to select the respondents for the study because a comprehensive list of the target population was not available. Respondents forming part of the target population were approached to complete a self-administered questionnaire. If the respondent refused to participate, the next available respondent adhering to the requirements of the population was requested to complete the survey.

In the end, the respondents interviewed seemed to be in a good position to comment on the experience they had had with their insurance agents, as most of them $(76 \%)$ had been doing business with their insurance agents for more than two years. The majority of the respondents further earned an income of more than R20 000 per month (69\%), and the respondents comprised an almost equal number of males (49.79\%) and females (50.21\%). Also, the majority of the respondents were between the ages of 18 and 47 years $(70 \%)$, and a total of $39 \%$ of the respondents were white, $51 \%$ were African and the remaining $10 \%$ of the sample comprised Coloured and Indian/Asian people. (The racial categories used are officially recognised and regarded as inoffensive designations in South Africa.)

It was decided to include a number of control variables in the survey that could affect the outcome of the study and which subsequently had to be controlled before the analysis could be concluded. The control variables included the types of financial services product bought (for example life insurance, retirement annuity policy, other investment products, medical aid) as well as the respondents' perceptions of customer satisfaction. Potential variation in responses due to the type of financial services product bought as well as the client's overall satisfaction with the service delivered had to be eliminated to obtain a true insight into the significance of the proposed model.

The questionnaire used in the survey firstly collected information on the demographic profiles of the respondents as well as the categorical variables measured, namely type of financial services product bought in the last ten years and whether the respondents thought the financial advice provided by the agent was of good quality. A five-point Likerttype scale ranging from "strongly disagree" (score 1) to "strongly agree" (score 5) was then used to design the continuous scale for measuring the respondents' perceptions regarding customer satisfaction, trust, commitment and customer loyalty. Previous studies conducted and validated by Du Plessis (2010) as well as Van Vuuren (2011) in the insurance and services industry informed the design of the questionnaire as well as the scale items that were listed under each construct. SPSS 22.0 and Amos 22.0 were used to analyse the empirical findings and to reach a conclusion on the hypotheses tested. 


\section{RESULTS}

A preliminary analysis was conducted first to ensure that the data set obtained adhered to the underlying assumptions required for conducting a hierarchical regression analysis.

\section{Preliminary Analysis}

A total of 262 respondents were approached and participated in the survey. Following a preliminary analysis of the empirical data, the decision was made to discard 20 questionnaires due to a large number of incomplete responses and to control for the effect of extreme rating patterns that were detected. The critical Mahalanobis distance values $20.515(d f=5), 22.458(d f=6)$ and $26.125(d f=8)$ as suggested Allen and Bennett $(2012$, p. 188) were used as a guideline. The remaining data set still contained a few missing responses (fewer than five values per construct). Mean substitution was used to replace these missing values, except in the instance where the respondents were requested to indicate the types of financial services products they had bought in the last ten years. The final sample size used in the analysis was therefore 242 respondents, representing a realisation rate of $92.37 \%$. This sample size was deemed adequate given the fact that it is larger than the required sample size of $50+8$ (number of variables investigated), as recommended by Tabachnick and Fidell (2013).

Furthermore, considering the fact that the sample size was greater than 200 respondents, the distribution of the data set did not require further investigation (Tabachnick \& Fidell, 2013, p. 80). Each category (construct) investigated comprised roughly the same number of cases, and the data were not collected in any group setting, or where the participants had any interaction with one another, which could have influenced the responses. No evidence of multicollinearity was detected, as the tolerance values as well as VIF values for all predictor variables investigated remained within the required parameters as outlined by Allen and Bennett $(2012$, p. 188). Finally, the normal probability plot and the scatterplot of standardised residuals evidenced that the assumptions of normality, linearity and homoscedasticity (Allen \& Bennett, 2012, p. 183) were met.

\section{Descriptive Statistics}

Only $56.4 \%$ of the respondents indicated that they had bought a life insurance policy from their insurance agent in the past ten years, $35.3 \%$ had bought a retirement annuity, $26.1 \%$ had bought other investment products such as an endowment policy, unit trusts and shares, and $22.8 \%$ had bought a medical aid policy. Furthermore, the majority of the respondents interviewed (72.5\%) indicated that they believed the financial advice provided by the agent had been of good quality.

Table 1 provides a summary of the means and standard deviations derived from the continuous variables examined. Customer satisfaction was rated highest by the respondents $(\mathrm{M}=3.898, \mathrm{SD}=0.787)$, followed by trust $(\mathrm{M}=3.679$, $\mathrm{SD}=0.847)$, customer loyalty $(\mathrm{M}=3.557, \mathrm{SD}=0.979)$ and customer commitment $(\mathrm{M}=3.555, \mathrm{SD}=0.872)$. Overall, it seems that the respondents tended to agree with the statements that were measured.

\section{Validity and Reliability}

Prior to the execution of the field study, face validity was obtained through the selection of scale items that seemed to fit well with the aspect they were intended to measure as well as the definition of the respective constructs. After the fieldwork was completed, a confirmatory factors analysis was performed to further assess the validity and reliability of the continuous variables measured.

The standardised factor loadings obtained (refer to Table 1) are all above the lower limit of 0.5 , as suggested by Hair, Anderson, Tatham, and Black (1995). All measurement items examined also loaded significantly onto their respective constructs $(p<0.01)$ and can consequently be deemed representative of the scales they were assigned to. The measurement model further provided good fit statistics and as such confirmed the presence of construct validity: $\chi^{2}(38)=95.127, \mathrm{CFI}=0.973, \mathrm{IFI}=0.973, \mathrm{RMSEA}=0.079, \mathrm{GFI}=0.934$ and $\mathrm{RFI}=0.936, \mathrm{Chisq} / \mathrm{df}=2.503$. 
Table 1 further provides a summary of the AVE values calculated for each construct. All values are above the lower threshold of 0.5 , thereby further indicating the presence of convergent validity. Finally, all constructs measured also appeared to be reliable as both the construct reliability values and the Cronbach's alpha values exceeded the lower limit of 0.7 .

Table 1. Validity, reliability and descriptive statistics

\begin{tabular}{|c|c|c|c|c|c|c|}
\hline Construct, item & $\begin{array}{c}\text { Standardised } \\
\text { factor loadings }\end{array}$ & Mean & SD & AVE & $\begin{array}{l}\text { Construct } \\
\text { reliability }\end{array}$ & \begin{tabular}{|c}
$\begin{array}{c}\text { Cronbach's } \\
\text { alpha }\end{array}$ \\
\end{tabular} \\
\hline Customer satisfaction & & 3.898 & 0.787 & 0.593 & 0.745 & 0.740 \\
\hline $\begin{array}{l}\text { I believe the service I received from my } \\
\text { financial adviser met my expectations. } \\
\text { It is my opinion that the financial adviser } \\
\text { treated me in a professional manner. }\end{array}$ & $\begin{array}{l}0.788 \\
0.752\end{array}$ & & & & & \\
\hline Trust & & 3.679 & 0.847 & 0.675 & 0.862 & 0.862 \\
\hline $\begin{array}{l}\text { I feel that the financial adviser acts in my } \\
\text { best interest. } \\
\text { It is my opinion that the financial adviser } \\
\text { is always honest with me. } \\
\text { I believe the financial adviser listens to } \\
\text { me when I speak. }\end{array}$ & $\begin{array}{l}0.843 \\
0.797 \\
0.824\end{array}$ & & & & & \\
\hline Commitment & & 3.555 & 0.872 & 0.635 & 0.838 & 0.835 \\
\hline $\begin{array}{l}\text { Doing business with the financial } \\
\text { adviser's practice has been worthwhile. } \\
\text { He/she makes annual adjustments to suit } \\
\text { my financial needs. } \\
\text { He/she has my best interest at heart. }\end{array}$ & $\begin{array}{l}0.810 \\
0.708 \\
0.864\end{array}$ & & & & & \\
\hline Customer loyalty & & 3.557 & 0.979 & 0.752 & 0.901 & 0.901 \\
\hline $\begin{array}{l}\text { I consider the financial adviser's practice } \\
\text { as my first choice amongst financial } \\
\text { advisers in Johannesburg. } \\
\text { I intend to stay in a loyal relationship } \\
\text { with the financial adviser's practice. } \\
\text { The relationship between the financial } \\
\text { adviser's practice and me is mutually } \\
\text { beneficial. }\end{array}$ & $\begin{array}{l}0.851 \\
0.873 \\
0.878\end{array}$ & & & & & \\
\hline
\end{tabular}

\section{Hypothesis Testing}

Table 2 reflects the findings of the hierarchical regression analysis conducted to test $\mathrm{H} 1$ and $\mathrm{H} 4$. $\mathrm{H} 1$ stated that quality advice has a significant positive relationship with trust towards the insurance agent. $H 4$ stated that quality advice has a significant positive relationship with commitment towards the insurance agent. Following the research findings it was possible to conclude that both hypotheses should be accepted. The standard regression coefficient for the relationship between quality advice and trust was $0.311(p<0.05)$, and for the relationship between quality advice and commitment it was $0.270(p<0.05)$. In addition, the change in adjusted $\mathrm{R}^{2}$ from the initial regression model (model 1), which includes the control variables life insurance, retirement annuity policy, other investment products, medical aid and customer satisfaction, to the model which added quality advice (model 2) was also statistically significant when both trust and commitment were measured as the dependent variables. 
Table 2. Regression results for models 1 and 2

\begin{tabular}{l|cc|cc}
\hline & \multicolumn{3}{|c}{ Trust } & \multicolumn{2}{c}{ Commitment } \\
\cline { 2 - 4 } & Model 1 & Model 2 & Model 1 & -0.072 \\
\hline Control variables & & & & -.013 \\
Life insurance & -0.081 & $-.120^{*}$ & -0.039 & -.002 \\
Retirement annuity policy & 0.052 & 0.022 & 0.013 & -.057 \\
Other investment products & -0.091 & $-0.097^{*}$ & 0.003 & $0.505^{*}$ \\
Medical aid & -0.061 & -0.060 & -0.058 & $0.270^{*}$ \\
Customer satisfaction & $0.733^{*}$ & $0.556^{*}$ & $0.658^{*}$ & 0.482 \\
Independent variable & & & \\
Quality advice & & $0.311^{*}$ & 0.046 \\
$\mathrm{R}^{2}$ & 0.553 & 0.615 & 0.435 & $p<0.0001$ \\
$\Delta \mathrm{R}^{2}$ & & 0.062 & & \\
Sig. of $\Delta \mathrm{R}^{2}$ & & $p<0.0001$ & & \\
\hline
\end{tabular}

Notes: Standardised regression coefficients were reported.

*Signifies statistical significance at $p<0.05$

Table 3 displays the findings of the hierarchical regression analysis conducted to test $\mathrm{H} 2$ and $\mathrm{H} 5$. H2 stated that trust has a significant positive relationship with customer loyalty towards the insurance agent, and H5 stated that commitment has a significant positive relationship with customer loyalty towards the insurance agent. Following the research findings it was also possible to accept these hypotheses. The standard regression coefficient for the relationship between trust and customer loyalty was $0.205(p<0.05)$, and for the relationship between commitment and customer loyalty it was $0.585(p<0.05)$. The change in adjusted $\mathrm{R}^{2}$ between model 1 and 2 as well as between model 2 and 3 was also statistically significant $(p<0.0001)$.

Hypotheses H3 and H6 stated that the relationship between quality advice and customer loyalty would be mediated by trust and commitment, respectively. To conclude on these hypotheses, it was necessary to test for full mediation. Firstly, evidence is required of a positive and significant relationship between quality advice and trust and well as between quality advice and commitment. Table 2 confirms these relationships. A positive and significant relationship is also required between quality advice and customer loyalty. This condition was met, as confirmed in Table 3 (model 2). A positive and significant relationship is further required between trust and customer loyalty as well as between commitment and customer loyalty. Lastly, a non-significant relationship is required between quality advice and customer loyalty after the effect of trust and commitment has been controlled. These conditions were also met, as indicated in Table 3 (model 3). The effect of work quality on customer loyalty became statistically insignificant after trust and commitment, both statistically significant, were added to the model. H3 and H6 can therefore also be accepted.

Table 3. Hierarchical regression models

\begin{tabular}{|c|c|c|c|}
\hline & \multicolumn{3}{|c|}{ Customer loyalty } \\
\hline & Model 1 & Model 2 & Model 3 \\
\hline Control variables & & & \\
\hline Life insurance & -0.058 & -0.094 & -0.027 \\
\hline Retirement annuity policy & 0.053 & 0.025 & 0.028 \\
\hline Other investment products & -0.63 & -0.069 & -0.048 \\
\hline Medical aid & -.097 & $-0.095 *$ & -0.050 \\
\hline Customer satisfaction & $0.655^{*}$ & $0.493 *$ & 0.084 \\
\hline $\begin{array}{l}\text { First level, independent variable } \\
\text { Quality advice }\end{array}$ & & $0.285^{*}$ & 0.064 \\
\hline $\begin{array}{l}\text { Second level, independent variable } \\
\text { Trust } \\
\text { Commitment } \\
\mathrm{R}^{2} \\
\Delta \mathrm{R}^{2} \\
\text { Sig. of } \Delta \mathrm{R}^{2}\end{array}$ & 0.449 & $\begin{array}{c}0.501 \\
0.052 \\
p<0.0001\end{array}$ & $\begin{array}{c}0.205^{*} \\
0.585^{*} \\
0.770 \\
0.270 \\
p<0.0001\end{array}$ \\
\hline
\end{tabular}

Notes: Standardised regression coefficients were reported.

*Signifies statistical significance at $p<0.05$ 


\section{DISCUSSION AND IMPLICATIONS}

Contributing to the literature, this study represents the first of its kind to investigate the mediating effect of trust and commitment on the relationship between quality advice and customer loyalty within the insurance agent environment. From the results, it was possible to propose a model that could be applied to the insurance agent context to foster customer loyalty. More particularly, it became evident that insurance agents should focus strongly on building trust and commitment. The addition of these mediating variables to the relationship between quality advice and customer loyalty contributes to a $27 \%$ change in the adjusted $\mathrm{R}^{2}$ value and resulted in a much higher $\mathrm{R}^{2}$ value of 0.77 in the final model (model 3). Insurance agents therefore cannot rely only on the provision of quality advice to ensure that their clients will remain loyal to them over the long term. It is also important to ensure that their clients perceive them as honest professionals who listen to their concerns and requests and have their best interest at heart. Furthermore, insurance agents should also ensure that their clients have the opinion that doing business with the practice is worthwhile, causing them to want to commit to the relationship at both a cognitive and an emotional level. Insurance agents, however, should be cautious about approaching trust and commitment as two separate paths for building customer loyalty. Although two intervening variables were examined, the presence of both trust and commitment is required for successful relationship marketing (Morgan \& Hunt, 1994). Customers who do not trust the provider will not be committed to the relationship (Nguyen \& Mutum, 2012, p. 407). Moreira and Silva (2015, p. 256) agree with this view and state that "If there is a positive relationship between trust and commitment, then both parties will generate enough value from their interaction and will be prepared to keep their commitment".

Additionally, the same model could be relevant to larger businesses making use of the consultative selling process. According to Newell, Belonax, McCardle, and Plank (2011, p. 307) salespeople have the option either to follow an approach of consultative selling or to form personal relationships to convince a customer to purchase a product. Consultative selling relates to a fact-driven process that entails questioning the customer and then providing a solution that will best address the problem. In contrast, sales consultants forming personal relationships with customers tend to focus more on obtaining an understanding of the customer's personal attributes and experiences. Newell, Belonax, McCardle, and Plank (2011, p.307) further argue that "consultative task behaviors lead to perceptions of expertise, whereas personal relationship behaviors lead to perceptions about trust". This approach to some extent "reflects the theme in the elaboration likelihood model (ELM) in which messages can be developed using either the central route (consultative), which focuses on fact-based, logic-oriented messages, or the peripheral route (relationship), which presents arguments with more emotionally based messages" (Newell, Belonax, McCardle, \& Plank, 2011, p. 307). While the general notion in practice is to follow either one of the two approaches, Newell, Belonax, McCardle, and Plank (2011, p. 307) conclude their argument by stating that it is more appropriate for salespeople to make use of both techniques for establishing long-lasting partnerships. Consequently, consultative sales personnel should not only provide quality advice after consulting with their clients but also focus on building personal relationships with them. This behaviour would contribute to the building of trust and consequently provide further support for the relationship between quality advice and trust, which was recommended in this study's proposed model.

From a business psychology perspective, the question that is left to be answered concerns the fundamental principles required for engaging consultative personnel and ensuring that they are well trained and motivated to establish trusting relationships. The success of the personal relationship-building approach will depend on the application of appropriate strategies to ensure that employees are engaged and in a position to perform their roles effectively. Possible interventions to implement include employing workers who are able to create trusting relationships with customers (Ben-Gal, Tzafrir, \& Dolan, 2015, p. 36) and providing training to develop their interpersonal skills. Future research should investigate this matter further and propose guidelines for improving practice in consultative selling. 


\section{LIMITATIONS AND OPPORTUNITIES FOR FURTHER RESEARCH}

The current study has a number of limitations and provides opportunities for further research.

Firstly, the context of the study was restricted to South Africa. A similar study could be conducted on a larger scale to measure the perceptions of respondents in multiple countries and could include other constructs that might influence customer loyalty. The study could be repeated in the selling environment of larger organisations, and scale items could be modified or added to further test the application of the proposed model in the consultative selling environment. More research is also needed on the interventions required for ensuring that employees are able to perform their roles effectively in establishing the necessary bond with the customer.

\section{SUMMARY}

Insurance agents globally often struggle with clients who do not understand the importance of disciplined saving and of meeting with the insurance agent at least once a year to make the necessary adjustments to their financial plans. It is however essential for these agents to build loyal relationships with their clients and to ensure that they are provided with the necessary advice and support for their financial well-being over the long term. Accordingly, the current study has proposed a model that offers guidelines for insurance agents to foster customer loyalty. The model indicates that it is essential for insurance agents not only to provide quality advice but also to ensure that they build trust and commitment to create long-lasting relationships. The findings of the study could also be of assistance to larger organisations focusing on consultative selling practices, and could assist them in creating solid client relationships that have the potential to deliver great profit. The theoretical and practical contribution of this study thus raises important implications for researchers and practitioners. From a business psychology perspective, more research is required to ensure that the model can be applied successfully in the consultative selling environment.

\section{AUTHOR BIOGRAPHIES}

Estelle van Tonder is an Associate Professor in the Program of Marketing at the North-West University and holds a DCom degree (Marketing Management) from the University of Pretoria. She was formerly the Head of Department in the School of Commerce at Milpark Education and prior to her position at Milpark Education, a senior lecturer in the Department of Marketing Management at the University of Johannesburg. Prof Van Tonder is a passionate researcher focusing on topics related to strategic marketing, services marketing and customer relationship management. She has published numerous articles in scholarly journals and has delivered papers at local and international conferences. Email: 25621610@nwu.ac.za.

\section{REFERENCES}

Allen, N. J. \& Meyer, J. P. (1990). The measurement and antecedents of affective, continuance, and normative commitment to the organization. Journal of Occupational Psychology, 63, 1-18.

Allen, P., \& Bennett, K. (2012). SPSS statistics: A practical guide. Version 20. Melbourne, Australia: Cengage.

Anderson, E. W., Fornell, C., \& Lehmann, D. R. (1994). Customer satisfaction, market share, and profitability: Findings from Sweden. Journal of Marketing, 58(3), 53-66.

Bansal, H. S., Irving, P. G., \& Taylor, S. F. (2004). A three-component model of customer commitment to service providers. Journal of the Academy of Marketing Science, 2(3), 234-250.

Barksdale, H. C. Jr., Johnson, J. T., \& Suh, M. (1997). A relationship maintenance model: A comparison between managed health care and traditional fee-for-service. Journal of Business Research, 40(3), 237-247.

Beatty, S. E., Reynolds, K. E., Noble, S. M., \& Harrison, M. P. (2012). Understanding the relationships between commitment and voice: Hypotheses, empirical evidence, and directions for future research. Journal of Service Research, 15(3), $296-315$.

Ben-Gal, H. C., Tzafrir, S., \& Dolan, S. (2015). Actionable trust in service organizations: A multi-dimensional perspective. Journal of Work and Organizational Psychology, 31, 31-39.

Berry, L. L. (1983). Relationship marketing. In L. L. Berry, G. L. Shostack, \& G. D. Upah (Eds.), Emerging perspectives of services marketing. Chicago, IL: American Marketing Association.

Bowen, J. T., \& Chen, S. L. (2001). The relationship between customer loyalty and customer satisfaction. International Journal of Contemporary Hospitality Management, 13(5), 213-217.

Cater, B., \& Zabkar, V. (2009). Antecedents and consequences of commitment in marketing research services: The client's perspective. Industrial Marketing Management, 38(7), 785-797. 
Chang, K.-C. (2013). How reputation creates loyalty in the restaurant sector. International Journal of Contemporary Hospitality Management, 25(4), 536-557.

Chaudhuri, A., \& Holbrook, M. B. (2001). The chain of effects from brand trust and brand affect to brand performance: The role of brand loyalty. Journal of Marketing, 65(2), 81-93.

Chiu, C.-M., Chang, C.-C., Cheng, H.-L., \& Fang, Y.-H. (2009). Determinants of customer repurchase intention in online shopping. Online Information Review, 33(4), 761-784.

Christiansen, T., \& DeVaney, S. A. (1998). Antecedents of trust and commitment in the financial planner-client relationship. Financial Counseling and Planning, 9(2).

Coelho, P. S., \& Henseler, J. (2012). Creating customer loyalty through service customization. European Journal of Marketing, 46(3/4), 331-356.

Crosby, L. A., Evans, K. R., \& Cowles, D. (1990). Relationship quality in services selling: An interpersonal influence perspective. Journal of Marketing, 54, 68-81.

Dagger, T. S., \& Brien, T. K. (2010). Does experience matter? European Journal of Marketing, 44(9/10), 1528-1552.

De Wulf, K., Odekerken-Schröder, G., \& Lacobucci, D. (2001). Investments in consumer relationships: A cross-country and cross-industry exploration. Journal of Marketing, 65(4), 33-50.

Dick, A. S., \& Basu, K. (1994). Customer loyalty: Toward an integrated conceptual framework. Journal of the Academy of Marketing Science, 22(2), 99-113.

Du Plessis, L. (2010). Customer relationship management and its influence on customer loyalty at Liberty Life in South Africa. (Master's thesis, University of Johannesburg, South Africa).

Ganesan, S. (1994). Determinants of long-term orientation in buyer-seller relationships. Journal of Marketing, 58(2), 1-19.

Garbarino, E., \& Johnson, M. (1999). The different roles of satisfaction, trust, and commitment in customer relationships. Journal of Marketing, 63 (April), 70-87.

Gefen, D. (2000). E-commerce: The role of familiarity and trust. Omega: The International Journal of Management Science, 28(6), 725-737.

Ghingold, M., \& Maier, K. C. (1986). Questioning the unquestioned importance of personal services in services marketing: Discussion and implication. Paper presented at the American Marketing Association Services Conference, Boston, MA.

Grönroos, C. (1994). From marketing mix to relationship marketing: Towards a paradigm shift in marketing. Management Decision, 32(2), 4-20.

Hair, J., Anderson, R., Tatham, R., \& Black, W. (1995). Multivariate data analysis with readings (4th ed.). Englewood Cliffs, NJ: Prentice-Hall.

Harris, L., \& Goode, M. (2004). The four levels of loyalty and the pivotal role of trust: A study of online service dynamics. Journal of Retailing, 80, 139-158.

Haywood, K. M. (1988). Repeat patronage: Cultivating alliances with customers. International Journal of Hospitality Management, 7(3), 225-237.

Hunt, K., Brimble, M., \& Freudenberg, B. 2011. Determinants of client-professional relationship quality in the financial planning setting. Australasian Accounting Business and Finance Journal, 5(2), 69-99.

Ibanez, V. A., Hartmann, P., \& Calvo, P. Z. (2006). Antecedents of customer loyalty in residential energy markets: Service quality, satisfaction, trust and switching costs. Service Industries Journal, 26(6), 633-650.

Iglesias, O., Singh, J. J., \& Batista-Foguet, J. M. (2011). The role of brand experience and affective commitment in determining brand loyalty. Journal of Brand Management, 18(8), 570-582.

Jacoby, J., \& Chestnut, R. W. (1978). Brand loyalty: Measurement and management. New York: Wiley.

Jones, T., Fox, G. L., Taylor, S. F., \& Fabrigar, L. R. (2010). Service customer commitment and response. Journal of Services Marketing, 24(1), 16-28.

Jones, T., \& Taylor, S. E. (2007). The conceptual domain of service loyalty: How many dimensions? Journal of Services Marketing, 21 (July), 20-38.

Kandampully, J., Zhang, T., \& Bilgihan, A. (2015). Customer loyalty: A review and future directions with a special focus on the hospitality industry. International Journal of Contemporary Hospitality Management, 27(3), 379-414.

Lariviere, B., Keiningham, T. L., Cooil, B., Aksoy, L., \& Malthouse, E. C. (2014). A longitudinal examination of customer commitment and loyalty. Journal of Service Management, 25(1), 75-100.

Lee, T. M. (2005). The impact of perceptions of interactivity on customer trust and transaction intentions in mobile commerce. Journal of Electronic Commerce Research, 63, 165-180.

Leverin, A., \& Liljander, V. (2006). Does relationship marketing improve customer relationship satisfaction and loyalty? International Journal of Bank Marketing, 24(4), 232-251.

Levitt, T. (1983). After the sale is over. Harvard Business Review, 61 (September/October), 87-93.

Lin, C. P., \& Ding, C. G. (2005). Opening the black box: Assessing the mediating mechanism of relationship quality and the moderating effects of prior experience in ISP service. International Journal of Service Industry Management, 16(1), 55-80.

Liu, C., Marchewka, J. T., Lu, J., \& Yu, C.-S. (2005). Beyond concern: A privacy-trust-behavioral intention model of electronic commerce. Information \& Management, 42(2), 289-304. 
Lovelock, C. H. (1983). Classifying services to gain strategic marketing insights. Journal of Marketing, 47 (Summer), 9-20.

Moorman, C., Deshpande, R., \& Zaltman, G. (1993). Factors affecting trust in market research relationships. Journal of Marketing, 57 (January), 81-101.

Moreira, A. C., \& Silva, P. M. (2015). The trust-commitment challenge in service quality-loyalty relationships. International Journal of Health Care Quality Assurance, 28(3), 253-266.

Morgan, R. M. \& Hunt, S. D. (1994). The commitment-trust theory of relationship marketing. Journal of Marketing, 58, 20-38.

Ndubisi, N. O. (2003a). Markets-marketers symbiosis under globalization: The aftermath of poor customer value. Academy of Marketing Studies, 8(1), 45-52.

Ndubisi, N. O. (2003b). Service quality: Understanding customer perceptions and reaction, and its impact on business. International Journal of Business, 5(2), 207-219.

Ndubisi, N. O. (2007). Relationship marketing and customer loyalty. Marketing Intelligence \& Planning, 25(1), 98-106.

Newell, S. J., Belonax, J. J., McCardle, M. W., \& Plank, R. E. (2011). The effect of personal relationship and consultative task behaviors on buyer perceptions of salesperson trust, expertise, and loyalty. Journal of Marketing Theory and Practice, $19(3), 307-316$.

Nguyen, B., \& Mutum, D. S. (2012). A review of customer relationship management: Successes, advances, pitfalls and futures. Business Process Management Journal, 18(3), 400-419.

Odekerken-Schröder, G., De Wulf, K., \& Schumacher, P. (2003). Strengthening outcomes of retailer consumer relationships: The dual impact of relationship marketing tactics and consumer personality. Journal of Business Research, 56(3), $177-190$.

Oliver, R. L. (1999). Whence customer loyalty? Journal of Marketing, 63, 33-44.

O'Mahony, G. B., Sophonsiri, S., \& Turner, L. W. (2013). The impact of the antecedents of relationship development on Thai and Australian resort hotels guests. International Journal of Hospitality Management, 34, 214-226.

O’Malley, L., \& Tynan, C. (2000). Relationship marketing in consumer markets: Rhetoric or reality? European Journal of Marketing, 34(7), 797-815.

Ou, W.-M., Shih, C.-M., Chen, C.-Y., \& Wang, K.-C. (2011). Relationships among customer loyalty programs, service quality, relationship quality and loyalty: An empirical study. Chinese Management Studies, 5(2), 194-206.

Pan, Y., Sheng, S., \& Xie, F. T. (2012). Antecedents of customer loyalty: An empirical synthesis and reexamination. Journal of Retailing and Consumer Services, 19(1), 150-158.

Petrick, J. F. (2004). Are loyal visitors desired visitors? Tourism Management, 25(4), 463-470.

Rapp, S., \& Collins, T. (1990). The great marketing turnaround. Englewood Cliffs, NJ: Prentice-Hall.

Rauyruen, P., \& Miller, K. E. (2007). Relationship quality as a predictor of B2B customer loyalty. Journal of Business Research, $60(1), 21-31$.

Reichheld, F. F. (1993). Loyalty-based management. Harvard Business Review (March/April), 64-73.

Reichheld, F. F. (1996). The loyalty effect. Boston, MA: Harvard Business School Press.

Reichheld, F. F., \& Sasser, E. W. (1990). Zero defections: Quality comes to services. Harvard Business Review, 68(5), $105-116$.

Roberts, K., Varki, S., \& Brodie, R. (2003). Measuring the quality of relationships in consumer services: An empirical study. European Journal of Marketing, 37(1/2), 169-196.

Roberts-Lombard, M., Van Tonder, E., Pelser, T. G., \& Prinsloo, J. J. (2014). The relationship between key variables and customer loyalty within the independent financial adviser environment. The Retail and Marketing Review, 10(1).

Rundle-Thiele, S. R., \& Bennett, R. (2001). A brand for all seasons: A discussion of loyalty approaches and their applicability for different markets. Journal of Product and Brand Management, 10(1), 25-37.

Sekhon, H., Roy, S. K., Shergill, G., \& Pritchard, A. R. (2013). Modelling trust in service relationships: A transnational perspective. Journal of Services Marketing, 27(1), 76-86.

Shafique, M. N., Ahmad, N., Abbass, H., \& Manzoor, R. (2015). Strengthen outcomes of insurance agent: An exploratory study in Pakistan. International Letters of Social and Humanistic Sciences, 8(2), 106-114.

Sharma, N., \& Patterson, P. G. (1999). The impact of communication effectiveness and service quality on relationship commitment in consumer professional services. International Journal of Services Marketing, 13(2).

Shoemaker, S., \& Lewis, R. C. (1999). Customer loyalty: The future of hospitality marketing. International Journal of Hospitality Management, 18(4), 345-370.

Silvestro, R., \& Cross, S. (2000). Applying the service profit chain in a retail environment: Challenging the satisfaction mirror. International Journal of Service Industry Management, 11(3), 244-268.

Singh, J., \& Sirdeshmukh, D. (2000). Agency and trust mechanisms in consumer satisfaction and loyalty judgments. Journal of the Academy of Marketing Science, 28 (Winter), 150-167.

Sumaedi, S., Bakti, I. G., Yuda, M., Rakhmawati, T., Astrini, N. J., Widianti, T., \& Yarmen, M. (2014). The empirical study on patient loyalty. Clinical Governance: An International Journal, 19(3), 269-283.

Tabachnick, B. G., \& Fidell, L. S. (2013). Using multivariate statistics (6th ed.). Boston: Pearson Education.

Toufaily, E., Ricard, L., \& Perrien, J. (2013). Customer loyalty to a commercial website: Descriptive meta-analysis of the empirical literature and proposal of an integrative model. Journal of Business Research, 66(9), 1436-1447.

Van Vuuren, T. (2011). Customer loyalty in an optometric practice: A case study perspective. (Master's dissertation, University of Johannesburg, South Africa). 
Walter, A., Muller, A. T., Helfert, G., \& Ritter, T. (2003). Functions of industrial supplier relationships and their impact on relationship quality. Industrial Marketing Management, 32(2), 159-169.

Wen, C.-H., Lan, L. W., \& Cheng, H.-L. (2005). Structural equation modeling to determine passenger loyalty toward intercity bus services. Transportation Research Record: Journal of the Transportation Research Board, No. 1927, $249-255$.

Yen, C.-H., Liu, L.-L., Tsai, F. C., \& Lai, C.-M. (2012). Life insurance service providers' attributes and relationship quality. Services Marketing Quarterly, 33(1), 16-33.

Yeske, D. B. (2010). Finding the planning in financial planning. Journal of Financial Planning, September.

Yoo, M., \& Bai, B. (2013). Customer loyalty marketing research: A comparative approach between hospitality and business journals. International Journal of Hospitality Management, 33, 166-177.

Zeithaml, V. A. (1981). How consumer evaluation processes differ between goods and services. In J. H. Donnelly, \& W. R. George (Eds.), Marketing of services (pp. 186-190). Chicago, IL: American Marketing Association. 